\title{
Manajemen Privasi Akun Model Hijab di Media Sosial Instagram
}

\author{
Dimas Ary Satria*1 \\ Ratri Kusumaningtyas ${ }^{2}$ \\ 1,2Program Studi Ilmu Komunikasi, Fakultas Komunikasi dan Informatika, \\ Universitas Muhammadiyah Surakarta, Indonesia \\ *e-mail: amenouzume3@gmail.com²
}

(Naskah masuk : tgl bln thn, Revisi : 2212 2021, Publikasi : 1301 2022)

\begin{abstract}
Abstrak
Penelitian ini bertujuan untuk menganalisis manajemen privasi model hijabers melalui privat akun di Instagram. Privat akun merupakan salah satu fitur di Instagram dimana pengguna mengunci akun sehingga tidak semua audiens bisa melihat aktivitas pengguna di Instagram. Teori Manajemen Privasi Manajemen digunakan dalam penelitian ini. Jenis penelitian ini yaitu penelitian kualitatif dengan metode deskriptif. Penelitian ini menggunakan teknik wawancara dalam memperoleh data primer dan dilakukan observasi akun Instagram untuk data sekunder. Data divalidasi menggunakan teknik triangulasi sumber. Hasil dalam penelitian ini menunjukkan bahwa model hijabers dalam manajemen privasi di Instagram dengan cara menggunakan privat akun Instagram dan mengatur konten unggahan dari foto, video maupun caption hingga adanya filter audiens karena merupakan ranah privasi mereka.
\end{abstract}

Kata kunci: Manajemen Privasi, Model Hijab, Privat Akun

\begin{abstract}
This study aims to analyze the privacy management of the hijabers model through private accounts on Instagram. Private accounts are one of the features on Instagram where users lock accounts so that not all audiences can see user activity on Instagram. Management Privacy Management Theory is used in this research. This type of research is qualitative research with descriptive methods. This study uses interview techniques in obtaining primary data and observations of Instagram accounts for secondary data are carried out. The data were validated using source triangulation techniques. The results in this study indicate that the hijabers model in privacy management on Instagram using privvate account Instagram and managing uploaded content both photos, videos, and caption to the presence of audiens fiters because it's their privacy.
\end{abstract}

Keywords: Hijabers Model, Privacy Management, Private Account

\section{PENDAHULUAN}

Peran media sangat dominan dalam membentuk perilaku dari aktor komunikasi (Kamilah \& Lestari, 2020). Kemajuan teknologi basis online memungkinkan pengguna untuk menyampaikan pesan tanpa memikirkan jarak. Seperti halnya dalam penggunaan media sosial khususnya Instagram. Media sosial satu ini memiliki fitur untuk berbagi foto maupun video dari pengguna. Sehingga Instagram menjadi ruang dalam pengungkapan diri yang memerlukan manajemen privasi yang baik.

Pada saat ini, populasi di dunia tidak dapat terhindar dari komunikasi melalui basis media telekomunikasi yang dipermudah dengan keberadaan Internet. Hal itu disebabkan karena dengan adanya sebuah teknologi yang mudah dan cepat, akan mempermudah pemenuhan kebutuhan komunikasi bagi seluruh manusia. Seiring dengan perkembangan waktu, internet saat ini telah memberikan sebuah jaringan baru yang dikenal dengan media sosial. Menurut Guzzetti (2006) dalam (Mustika, 2018) dengan adanya sebuah media sosial tersebut, individu dapat ikut serta dalam berbagi informasi maupun menjalin pertemanan dengan orang lain sehingga mendapatkan umpan balik tentang dirinya.

Media sosial merupakan sebuah bentuk inovasi dari perkembangan teknologi komunikasi. Bahkan dalam realitasnya, media sosial banyak sekali digunakan oleh seluruh kalangan usia. Dari beberapa banyaknya media sosial yang ada saat ini, salah satu diantaranya yang banyak digunakan adalah Instagram. Dikutip goodnewsfromindonesia.id dari data yang dilansir oleh 
Napoleon Cat pengguna Instagram di Indonesia pada periode Januari-Mei 2020 mencapai 69.270.000 pengguna (Iman, 2020). Suatu bentuk aplikasi media sosial yang sangat populer ini, pengguna dapat menggunakan berbagai fitur yang sangat menarik yaitu dapat membagikan foto, vidio serta pengguna lain dapat memberikan feedback berupa like maupun komen. Alkandari dalam (Lestari \& Kusuma, 2019) menyebutkan beberapa motif menggunakan instagram, antara lain sebagai ekspresi diri, interaksi sosial, pembentuk opini, ruang eksperimen dan pemenuhan hiburan.

Pengguna Instagram yang populer atau selebriti dalam Instagram saat ini mulai bermunculan. Dimana pengguna Instagram yang populer di kalangan pengguna lain disebut dengan istilah selebgram (Krisnawati, 2016). Kemunculan selebgram dapat dimanfaatkan dari berbagai bidang, salah satunya adalah sebagai media promosi. Anshar dalam (Sakinah, 2018) menyatakan bahwa terdapat pengaruh positif yang diberikan oleh selebgram dalam mempengaruhi keputusan dan pemilihan produk audiens. Terlebih selebgram juga dapat menjadi panutan dalam segi fashion bagi pengikutnya sehingga dapat meningkatkan nilai beli konsumen (Sakinah, 2018). Terdapat banyak macam selebgram di Instagram, dimana dalam penelitian ini selebgram merujuk pada model hijabers.

Melihat perkembangan penggunaan busana dan cara orang untuk berpakaian dapat mendefinisikan diri mereka sendiri. Tidak terkecuali perkembangan busana hijab. Terlebih hijab memberikan kesempatan bagi perempuan untuk dapat menentukan identitas diri mereka (Huromaini, 2017). Hijab sendiri juga merupakan busana dari cerminan perempuan yang Islami. Tren hijabers saat ini lebih mengedepankan cara berpakaian yang fashionable dan modern membuat model hijabers mulai bermunculan (Huromaini, 2017). Model hijabers seringkali dilakukan oleh pengguna akun yang memiliki pengikut yang banyak dan memiliki citra positif.

Dari penggunaan media sosial, terdapat fenomena kejahatan berupa cyberstalking yaitu kejahatan yang dilakukan oleh seseorang dengan memperhatikan, menghubungi, hingga menyalahgunakan informasi korban secara berulang ulang (Putri, Nirwana \& Sobari, 2010). Dampak dari perilaku cyberstalking dalam penelitian (Putri, Nirwana \& Sobari, 2010), memunculkan rasa takut, cemas dan korban menjadi lemah. Di ranah Instagram, sempat terjadi fenomena swafoto yang sempat diteliti oleh (Ardiyanti, 2018). menyatakan, dalam swafoto dapat memunculkan kekhawatiran terkait identitas pengguna baik meliputi ranah privasi, identitas, keamanan dan pengawasan.

Seiring berjalanya aktivitas penggunaan Instagram yang semakin kompleks ini menimbulkan adanya ranah privasi. Keseimbangan antara privasi dan keterbukaan memiliki makna karena hal ini sangat penting terhadap cara kita mengelola hubungan dan membentuk citra diri (Ardiyanti, 2018). Sehingga pengguna saat ini dapat mengunci akun yang biasa dikenal dengan private akun. Dengan mengunci akun, apa yang telah diunggah melalui Instagram hanya dapat di lihat oleh orang yang telah mengikuti saja.

Menurut Louis Alvin Day (2006) dalam (Mustika, 2018) privasi sebenarnya sebagai hak yang dimiliki individu untuk mengontrol publikasi yang diinginkan dan tidak diinginkan tentang urusan personal seseorang. Dalam menyebarkan pesan yang bersifat personal biasanya dibutuhkan keintiman dalam suatu proses hubungan. Terdapat strategi dari masing masing individu untuk membuat keputusan tentang mengungkapkan dan menyembunyikan informasi personal yang dimana jika setiap individu membuka informasi, maka akan ada resiko dan keuntungan yang timbul (Mustika, 2018). Sehingga diperlukan adanya pengelolaan privasi yang seimbang dalam Instagram terlebih merupakan salah satu media sosial dengan ranah yang luas. Pengguna media sosial melindungi diri mereka dengan kontrol tertentu karena adanya resiko privasi online (Suh \& Hargittai, 2015).

Hasil observasi pra penelitian yang dilakukan oleh penulis menunjukan bahwa banyak model yang mengunci akun Instagram. Salah satu informan model hijab di Surakarta menggunakan kunci akun dengan alasan agar informasi mengenai unggahnya hanya diketahui oleh teman terdekatnya. Kemudian model hijab lain yang menggunakan kunci akun Instagram yang menggunakan privat akun Instagram dengan memiliki 3.106 pengikut dengan alasan agar lebih terjaganya ranah privasi dan tidak suka akunnya dilihat orang lain selain pengikutnya. Selain

JISHI 
mengontrol informasi privat dan mengelola privasi, terdapat aspek dialektis ketika menyampaikan informasi privat (Sugiarto, 2017).

Dilansir laman CNBC, setidaknya terdapat 214 juta data pribadi dari pengguna media sosial di curi salah satunya adalah dari Instagram. Data yang dicuri ini termasuk nomor telepon, nama lengkap, hingga data lokasi. Dalam kasus selebgram cilik dikatakan foto-foto pribadi dapat direkayasa dan dapat dipergunakan dalam kejahatan (Krisnawati, 2016). Sehingga dalam penggunaan media sosial oleh model hijab juga memerlukan privasi manajemen.

Karena penelitian terkait model hijabers dalam media sosial dalam realitasnya memerlukan manajemen privasi pada saat pengaplikasian Instagram. Model hijabers sebagai pengguna Instagram yang memiliki jumlah pengikut yang relatif banyak dan kontrol batasan, alasan dalam melakukan privat akun hingga ketengan yang dialami ketika menggunakan Instagram. Dari uraian latar belakang tersebut, penelitian ini memiliki rumusan masalah yaitu Bagaimana "Manajemen privasi melalui privat akun yang dilakukan seorang model hijabers di Instagram?"

Dalam penelitian ini, peneliti memilih teori Teori Manajemen Privasi karena merupakan salah satu teori yang memberi pandangan mengenai fenomena ketika sebuah individu menjadi alat untuk memeriksa regulasi pengungkapan dan perlindungan informasi pribadi dalam konteks yang luas (Mustika, 2018). Petronio pada tahun 1991, pada teori ini disebut sebagai teori komunikasi batas manajemen. Yang kemudian berubah menjadi Teori Manajemen Privasi pada tahun 2002. Pilihan dan peraturan yang dimiliki oleh suatu individu didasarkan pada pertimbangan akan individu lain dan juga konsep diri yang dimiliki. Petronio menyampaikan bahwa manajemen privasi merupakan proses yang dialektis (Nurbaiti \& Anshari, 2020). CPM juga merupakan alat yang berguna untuk membingkai studi tentang pengelolaan studi dalam penggunaan media sosial (Hollenbaugh, 2019).

Informasi privat merupakan sebuah informasi yang bersifat pribadi bagi sebuah individu. Adanya batasan membuat individu mengelola konteks informasi yang dibagikan kepada individu lain, sehingga diperlukan kontrol dan koordinasi yang baik (Ardiyanti, 2018). Ketika individu memiliki informasi yang bersifat privat, mereka berada dalam posisi mengontrol dan koordinasi siapa saja yang dapat mengakses informasi tersebut. Pada umumnya pengguna akan melakukan segalanya untuk melindungi informasi privat (Wolf, 2019).

Ketika sudah berada di dalam media, untuk mencapai aktualisasi diri diperlukan adanya motivasi guna mendapatkan umpan balik (Ardiyanti, 2018). Teori CPM juga memprediksi faktor kontekstual mempengaruhi aturan privasi (Beam \& Child, 2018). Faktor pendorong individu membuka informasi privatnya, yaitu untuk membangun kepercayaan dalam sebuah hubungan, untuk mengurangi beban ketika individu tersebut sedang mengalami stress dan gangguan psikologis, dan karena adanya rasa ingin tahu yang sangat besar dilakukan secara terus menerus oleh individu lain. Sebaliknya alasan yang membuat seorang individu menutup informasi privat yang dimilikinya, yaitu karena takut keberadaannya ditolak oleh orang-orang di sekitarnya, maupun individu tersebut tidak ingin merusak perannya sebagai figur yang memiliki citra yang positif. Individu seringkali menyembunyikan informasi terhadap orang lain ketika kebutuhan individu tersebut untuk terbuka rendah (West \& Turner, 2010) dalam (Mustika, 2018).

Kontrol individu dalam komunikasi di media sosial dapat mempengaruhi manajemen privasi individu dalam menjalin hubungan (Wolf, 2019). Guna untuk membangun dan mengatur konteks dimana pengguna dapat mengungkapkan informasi, pengguna aktif media sosial juga melakukan pemantauan dan mengontrol pengungkapan mereka. Menurut Petronio (2002) dalam (Masur \& Scharkow, 2016) dengan kondisi teori manajemen privasi, semua pesan yang disampaikan menjadi pemilik bersama dari setiap informasi pengguna mengungkapkan kepada mereka.

Terdapat kepribadian extravert dan introvert yang dimiliki oleh individu. Dimana pada kenyataanya individu dengan kepribadian extravert lebih mengungkapkan privasinya pada media sosial dibanding dengan kepribadian introvert (Ardiyanti, 2018). Dalam pengambilan keputusan sebelum pengungkapan, terdapat lima kriteria seperti kriteria budaya, kriteria gender, kriteria 
kontekstual, kriteria motivasi, dan kriteria rasio resiko yang menjadi pertimbangan, Griffin dalam (Kamilah \& Lestari, 2020).

Ketika individu dihadapkan pada pilihan untuk membuka atau menutup diri kepada orang lain, di dalam diri individu tersebut akan ada gaya tarik menarik untuk mengungkapkan atau tetap menyimpan informasi privat tersebut. Gaya tarik menarik untuk mengungkapkan atau tetap menyimpan informasi privat inilah yang disebut dengan ketegangan dialektik (Sugiarto, 2017).

Penelitian yang telah dilakukan sebelumnya, yang juga menjadi rujukan peneliti adalah penelitian dengan judul "Privasi pada Remaja di Media Sosial" penelitian ini menemukan alasan seseorang harus menjaga privasi di internet dan bentuk-bentuk pelanggaran privasi seperti mengintervensi wilayah personal seseorang tanpa ijin dari orang yang bersangkutan. Persamaan dari penelitian yang dilakukan penulis adalah menggunakan teori Communication Privacy Management Theory. Remaja menganggap media sosial merupakan tempat ideal untuk bereksperimen dan melakukan eksplorasi pencarian identitas. Namun remaja juga harus sadar sebagai pemilik utama dari informasi, secara aktif akan melakukan kontrol atas apa, kapan, dan kepada siapa informasi pribadi tersebut dibagikan (Mustika, 2018).

Selanjutnya penelitian yang berjudul "Contextualizing how teens manage personal and interpersonal privacy on social media" Penelitian ini menemukan kontrol individu dalam lingkungan jejaring sosial, secara positif diperlukan kontrol keputusan terkait dengan manajemen privasi interpersonal. Juga, privasi interpersonal manajemen penting ketika mengoordinasikan batas dengan rekan-rekan daripada saat mengoordinasikan materi seksual, dan berurusan dengan informasi pribadi yang dibagikan oleh orang tua. (Wolf, 2019).

Selanjutnya penelitian yang berjudul "Disclosure Management on Social Network Sites: Individual Privacy Perceptions and User-Directed Privacy Strategies" penelitian ini menemukan pengguna media sosial melihat informasi tertentu sebagai pribadi yang berbeda tergantung pada preferensi privasi pribadi dan pengungkapan manajemen privasi mempertimbangkan saluran komunikasi dan tipe informasi selanjutnya menemukan kepercayaan penggunaan pengaturan privasi secara signifikan memengaruhi manajemen pengungkapan dalam pembaruan status maupun percakapan obrolan. (Masur \& Scharkow, 2016).

Dari penelitian terdahulu yang menjadi rujukan, memiliki persamaan pada manajemen privasi yang peneliti lakukan. Kesamaan juga terdapat pada penggunaan teori pada penelitian. Namun, perbedaan terdapat pada subjek penelitian dimana peneliti memilih untuk meneliti model hijabers di media sosial Instagram.

Tujuan dari penelitian ini adalah menganalisis manajemen privasi model hijabers melalui privat akun di Instagram. Adapun rumusan masalah dalam penelitian ini adalah untuk mengetahui bagaimana model hijaber mengelola privasi akun Instagram mereka.

\section{METODE}

Peneliti memilih untuk menggunakan metode kualitatif dengan tipe deskriptif dikarenakan pada penelitian ini tidak menyajikan secara statistik seperti tidak menggunakan angka-angka. Peneliti biasanya menggunakan pendekatan alamiah untuk melihat sebuah fenomena. Penelitian kualitatif berupaya untuk memperoleh sebuah pemahaman, pencerahan tentang sebuah fenomena dan pencarian pada konteks yang sama (Anggito \& Setiawan, 2018). Subjek dalam penelitian ini dapat disebut sebagai informan dan menjadi sampel yang digunakan untuk memperoleh data. Di dalam penelitian ini subjek penelitiannya adalah model hijabers asal Surakarta yang menggunakan privat akun Instagram. Obyek dalam penelitian ini dapat disebut sebagai fokus dari apa yang diteliti dan objek dalam penelitian ini adalah private akun Instagram. Pengumpulan data yang dilakukan dalam penelitian ini menggunakan pengumpulan data primer dan juga data sekunder. Data primer didapat dari sebuah wawancara pengguna private akun model hijabers Surakarta mengenai Manajemen Privasi mereka terkait alasan menggunakan private akun Instagram. Observasi juga dilakukan untuk memperoleh data sekunder melalui pengamatan akun Instagram model hijabers, sehingga dapat memahami konteks objek penelitian secara menyeluruh. Dan data sekunder didapat dari dokumentasi dalam bentuk rekaman maupun 
foto pada saat wawancara serta bukti screenshot Private akun Instagram supaya data yang didapat menjadi lebih valid.

Teknik Sampling dalam penelitian ini menggunakan teknik purposive sampling (non probability sampling). Teknik purposive sampling ini merupakan sebuah cara pengambilan sampel dengan mencari ciri-ciri khusus sesuai dengan tujuan penelitian yang dilakukan agar bisa menjawab masalah penelitian (Kriyantono, 2014). Dalam penelitian ini menggunakan 4 informan model hijabers yang digunakan untuk memperoleh data. Adapun kriteria sebagai berikut: (1) Model hijabers berdomisili di Surakarta, (2) Menggunakan Instagram memiliki lebih dari 700 pengikut, (3) Menggunakan private akunPenelitian ini mengguanakan Analisis data Miles dan Huberman yaitu meliputi berberapa 3 komponen yang digunakan untuk penyusunan penelitian (Sugiyono, 2010). Reduksi data yaitu proses merangkum dengan memilih data-data yang penting dan pokok, serta membuang data-data yang sekiranya tidak perlu didalam penelitian. Penyajian data dalam peneltian ini dilakukan dalam bentuk uraian dari sudut pandang pengguna aktif sosial media Instagram yang menggunakan private akun. Miles dan Huberman menyatakan bahwa yang paling sering digunakan dalam penyajian data dalam penelitian kualitatif adalah dengan teks yang bersifat naratif. Penarikan Kesimpulan Menurut Miles dan Huberman merupakan langkah yang terakhir pada analisa data kualitatif. Kesimpulan permulaan yang telah dikemukakan masih merupakan data sementara dan masih bisa berubah jika di temukan bukti-bukti valid saat peneliti kembali untuk mengumpulkan data dilapangan dan kesimpulan yang dikemukakan merupakan kesimpulan yang bisa dipercaya.

Validasi data dalam penelitian diperlukan untuk membuat hasil dari penelitian menjadi valid. Jenis triangulasi yang digunakan dalam penelitian adalah triangulasi sumber. Triangulasi sumber memastikan bahwa data yang di dapat tidak direkayasa. Dalam penelitian ini, triangulasi sumber dilakukan oleh peneliti menggunakan jurnal penelitian terdahulu sebagai pembanding data yang didapat saat penelitian untuk keperluan pengecekan. Di dalam pengumpulan sebuah data peneliti memperoleh ketidaksamaan pendapat dari narasumber satu dengan yang lainnya (Sugiyono, 2010).

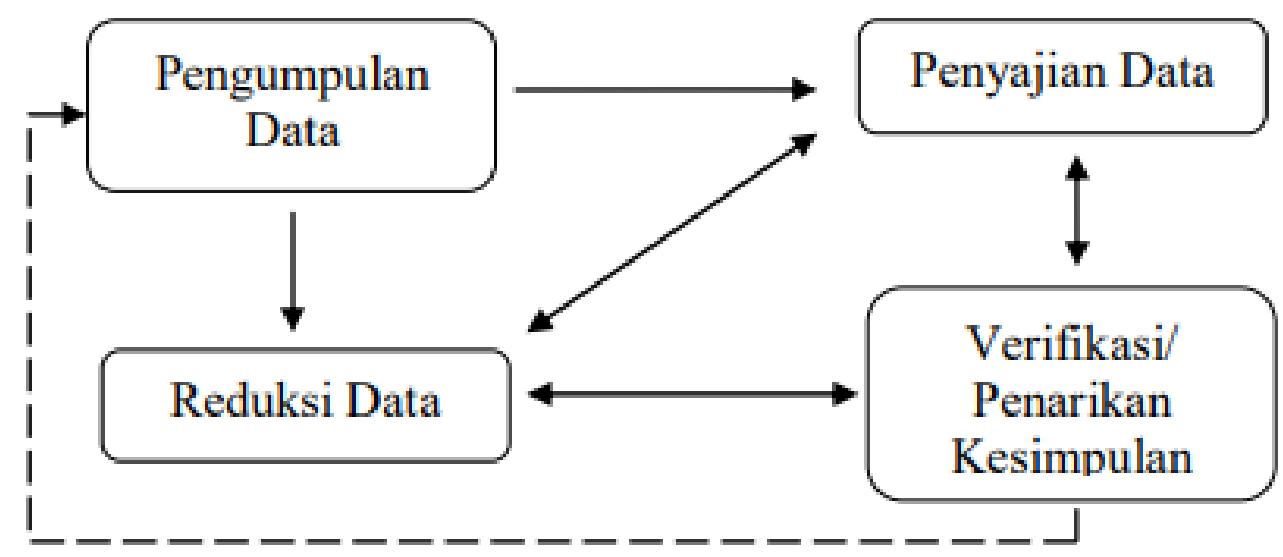

Gambar 1. Alur penelitian

\section{HASIL PENELITIAN}

Dari hasil penelitian yang peneliti lakukan pada tanggal 1 Maret 2021 hingga 20 April 2021 melalui wawancara secara langsung informan secara face to face dan juga dilakukan via online melalui Whatsapp call. Dimana pada wawancara melibatkan 4 model hijabers Surakarta, diantaranya:

Tabel 1. Gambaran Informan

\begin{tabular}{ccc}
\hline Informan & Jumlah Followers & Lama Menjadi Model Hijab \\
\hline 1 & 1857 & 6 tahun \\
2 & 1838 & 3 tahun \\
3 & 3538 & 3 tahun \\
4 & 753 & 1 tahun \\
\hline
\end{tabular}


Selanjutnya dalam penelitian ini, observasi akun Instagram model hijabers dilakukan untuk memperoleh data sekunder penelitian. Peneliti memiliki kriteria saat menentukan informan salah satunya kriterianya adalah pengguna akun privat di media sosial Instagram. Sehingga masing masing informan yang digunakan dalam penelitian ini merupakan pengguna privat akun Instagram secara keseluruhan.

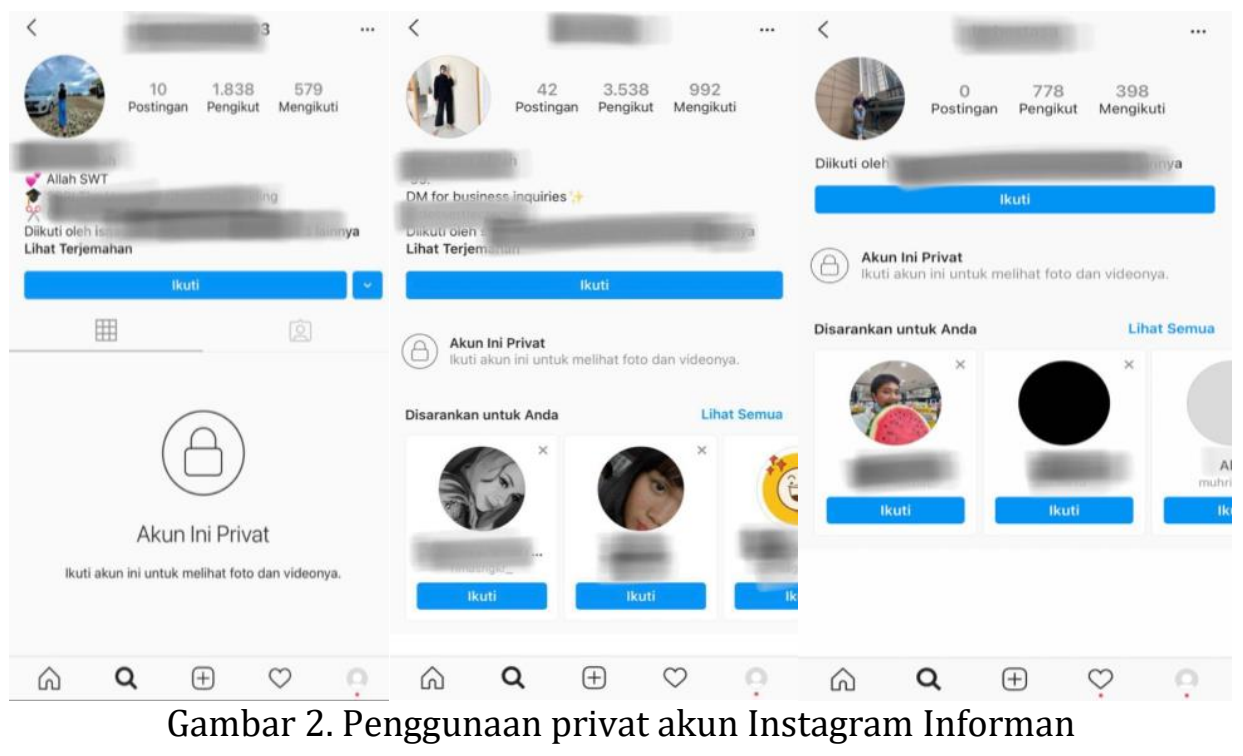

Pada hasil dan pembahasan penelitian ini disusun berdasarkan teori Communication Privacy Management. Dimana teori ini berfokus pada 3 bagian yaitu: Informasi privat, batasan privat, dan Ketegangan dialektis.

\subsection{Alasan Menutup Informasi Privat}

Terdapat beberapa alasan yang dapat mendorong model hijabers dalam membuka dan menutup informasi privat dalam Instagram. Dari hasil wawancara yang dinyatakan oleh informan, mereka menyatakan beberapa ruang informasi privat yang tidak bisa di bagikan ke dalam media sosial Instagram. Informasi tersebut diantaranya kontak pribadi, tempat tinggal, hingga keluarga. West \& Turner menyatakan individu seringkali menyembunyikan informasi terhadap orang lain ketika kebutuhan individu tersebut untuk terbuka rendah, tidak memiliki keuntungan yang didapat oleh individu tersebut (Mustika, 2018). Data yang sama diperoleh setiap informan dalam wawancara.

"Tentunya bagian dari diri kita yang tidak bisa di share ke media sosial ataupun mungkin cukup kita saja yang tau contohnya seperti keluarga, seperti kita punya rahasia di keluarga, cukup hanya kita saja yang tau dan juga temen yang sudah kita percaya ataupun yang sudah dekat dengan saya, mungkin tidak usah kita kita share ke media sosial" (Informan 2).

"Kalo menurut ku itu informasi itu kaya tentan hal hal pribadiku sepeti nomer telfon, alamat tempat tinggal"( Informan 3).

Terdapat 2 pandangan yang mendorong individu untuk menutup informasi privatnya dengan menggunakan privat akun Instagram, yaitu untuk membangun rasa aman secara psikologis karena terjaganya informasi privat seperti pernyataan informan 1 dan 2, lalu kedua sebagai filter audiens tidak dikenal agar informasi yang dimiliki informan tidak disalahgunakan dalam pernyataan informan 3 dan 4 . Temuan ini sesuai dengan penelitian terdahulu berjudul "Manajemen Privasi pada Pengguna Media Sosial" Instagram terkait alasanya membuat para pengguna Instagram melakukan manajemen privasi pada akun Instagramnya karena ingin merasa aman akan adanya penyalahgunaan informasi privasi mereka (Kamilah \& Lestari, 2020). Dalam hal ini dinyatakan oleh informan pada saat wawancara.

"Tentunya biar aman, biar orang yang ada diakun saya orang yang aku kenal, tidak ada 
orang yang dari luar yang gak aku kenal ya intinya teman yang aman saja yaitu teman yang saya kenal saja" (wawancara informan 2, 22 April 2021)

"Biar memfilter orang-orang yang tidak dikenal aja sih, karena di ig ku tuh banyak fake akun yang gak jelas yang suka ngepoin kaya nefollow atau nge dm dan aku tu pengennya ig tuh isinya hanya orang yang aku kenal dan orang dekat saja" (wawancara informan 4, 22 April 2021)

Selain itu terdapat informan yang juga memiliki pertimbangan dalam membagikan sebuah informasi privat. Dalam temuan penelitian model hijabers merasa bahwa batas rasa aman saat membagikan informasi kepada teman bersifat personal. Seperti yang ditemukan dalam penelitian Gruzd \& Hernández-García, bahwa meskipun informasi tersedia untuk umum di media sosial, pengguna mungkin masih mengharapkan privasi (Dianiya, 2021). Dinyatakan oleh West \& Turner, individu memutuskan untuk menutup informasi privat yang dimilikinya karena takut keberadaannya ditolak oleh orang-orang di sekitarnya, individu tersebut takut membuat psikologis orang lain menjadi terganggu, serta individu tersebut tidak ingin merusak perannya sebagai figur yang pantas untuk diteladani individu tersebut tidak memiliki kebutuhan untuk terbuka terhadap orang tersebut. Individu seringkali menyembunyikan informasi terhadap orang lain ketika kebutuhan individu tersebut untuk terbuka rendah (Mustika, 2018).

"Tentunya teman yang aman tadi itu mas, karena kalau saya ngeshare informasi kepada orang orang yang sudah saya kenal itu otomatis dia aman dan juga bisa menjaga privasi saya" (wawancara informan 2, 22 April 2021).

Dapat disimpulkan bahwa dalam alasan menutup informasi privat dengan menggunakan privat akun di Instagram, model hijabers memiliki keinginan untuk membuat informasi privat menjadi lebih terjaga sehingga memberi rasa aman secara sosial. Hal ini serupa dengan penelitian terdahulu berjudul Management privacy dalam penggunaan fitur "close friend" di Instagram dimana dalam penelitian tersebut ditemukan privat akun menjadi lebih aman saat membagikan foto maupun video (Dianiya, 2021). Akan tetapi keunikan terjadi ketika model hijabers dalam Instagram berperan sebagai pembentuk citra sebuah produk hijab. Alasan yang membuat seorang individu memutuskan untuk menutup informasi privat yang dimilikinya, yaitu karena takut keberadaannya ditolak oleh orang-orang di sekitarnya, individu tersebut takut membuat psikologis orang lain menjadi terganggu, serta individu tersebut tidak ingin merusak perannya sebagai figur yang pantas untuk diteladani individu tersebut tidak memiliki kebutuhan untuk terbuka terhadap orang tersebut (Mustika, 2018).

"Terus takut kalo ada orang yang insecure melihat apa yang aku post karena kan gak semua orang seberuntung kita pasti ada aja orang yang ingin di posisi kita jadi aku tu ngehargain aja ke sesama perempuan" (wawancara informan 422 April 2021)

\subsection{Cara Mengontrol Informasi Privat}

Informasi privat merupakan sesuatu rahasia, yang artinya informasi tersebut sangat berarti bagi mereka (Kamilah \& Lestari, 2020). Sehingga diperlukan kontrol untuk memberikan kesejahteraan bagi individu. Kontrol sebuah informasi juga diperlukan dalam menggunakan Instagram. Model hijabers dalam menggunakan Instagram melakukan filter dalam penggunaan konten dan tidak membagikan kontak personal sebagai kontrol informasi privat. Proses selektif dalam memilih pengikut Instagram dengan cara pengaktifan fitur private account sehingga dapat menyortir terlebih dahulu siapa yang dapat melihat profil dengan anggapan memprivasi akun tersebut mereka dapat lebih aman dalam membagikan konten foto dan video (Dianiya, 2021). Hal ini dinyatakan saat wawancara masing masing informan memiliki kesamaan dalam selektif saat menggunakan akun Instagramnya.

"Sebenarnya memilah/memilih apa yang akan aku upload di Instagram, apa yang orang lain boleh tau tentang aku dan tidak boleh tau tentang aku, contoh keseharian aku suka makan, aku bakalan sharing aku kali ini makan apa tetapi kalo masalah pribadi aku gakpernah upload (tentang kehidupan pribadi aku)" (wawancara informan 1, 24 April 2021)

"Kaya lebih milih2 gitu apa yang di taruh diakun ig kaya naruh nomer kontak hp, email. Akun sendiri itu gak nyaman takutnya ada orang yang iseng gak jelas maksud dan tujuannya apa kalo memang ada kepentingan gitu biasanya nge dm terus baru ngungkapkan kepentingannya

JISHI 
apa, sehingga tidak sembarang orang menghubungi nomer" (wawancara informan 4, 22 April 2021)

Koidl \& Kapanova menyatakan untuk mengatasi aspek kepercayaan, dalam beberapa tahun terakhir, beberapa platform baru telah muncul yang berupaya membuat interaksi antar pengguna lebih dapat dipercaya (Dianiya, 2021). Pilihan tersebut juga berlaku pada penggunaan Instagram di mana pengguna diberikan hak untuk membatasi informasi pada profil hanya kesebagian orang saja serta dapat memilih apakah profil dan/atau fitur berbagi cerita ingin ditampilkan secara publik atau tidak. Salah satu caranya yaitu dengan menggunakan fitur di Instagram yaitu privat akun. Dengan privat akun, pengguna dapat menentukan dengan siapa saja dia mau berbagi aktifitas keseharian khususnya dalam unggahan dan insta story di Instagram. Temuan ini memiliki kesamaan dengan penelitian terdahulu berjudul Management privacy dalam penggunaan fitur "close friend" di Instagram dimana dalam temuanya informan menentukan kepada siapa saja audiens yang boleh melihat aktivitasnya di media sosial Instagram (Dianiya, 2021).

Walaupun orang-orang yang bertemu muka tersebut tidak saling berbicara atau tidak saling menukar tanda, interaksi sosial telah terjadi, karena masing-masing sadar akan adanya pihak lain yang menyebabkan perubahan-perubahan dalam perasaan (Nainggolan, Rondonuwu, \& Waleleng, 2017). Penggunaan akun privat dalam media sosial Instagram informan membuat rasa aman dan nyaman ketika memberikan umpan balik komentar dalam unggahan. Informan merasa karena adanya filter yang dilakukan saat akan memperbolehkan siapa saja yang melihat aktivitasnya di Instagram adalah orang yang dipercaya. Terlihat dalam temuan observasi akun instagram informan, mereka aktif dalam memberikan umpan balik komentar tanpa adanya tekanan dengan ditunjukan umpan balik terhadap orang lain yang memiliki kedekatan secara personal.

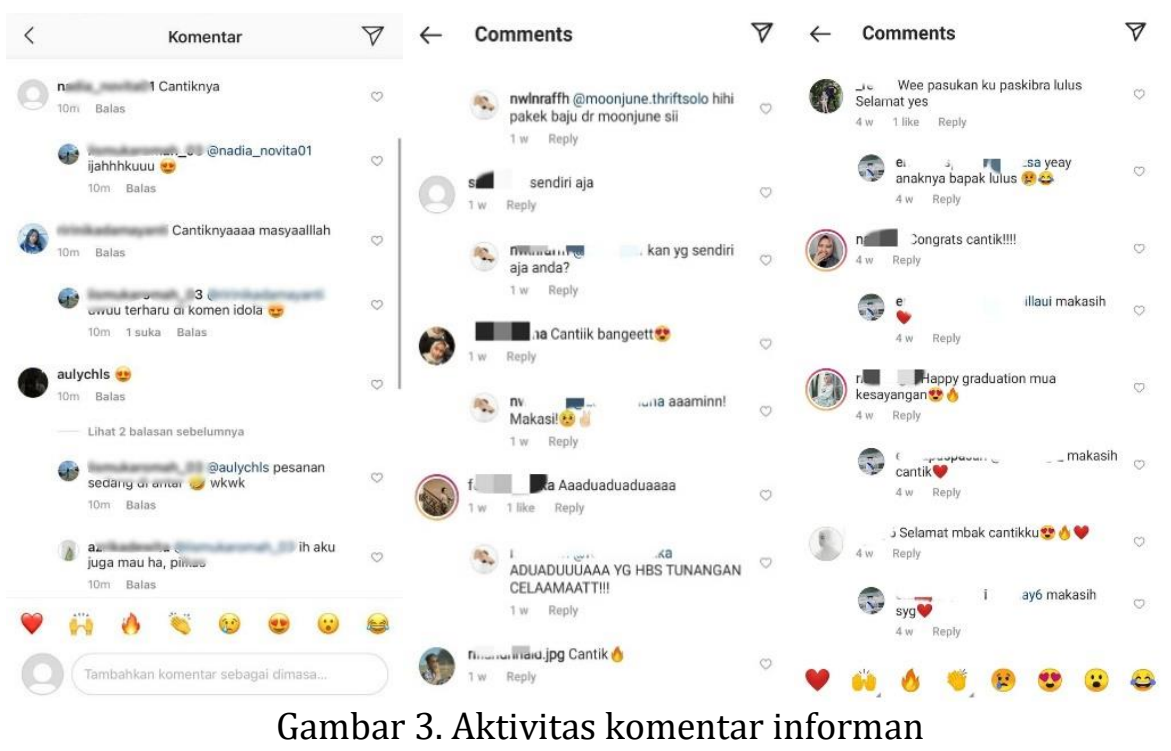

Terjadi perbedaan yang dilakukan oleh informan 4, dimana dalam akun Instagramnya tidak memiliki sebuah unggahan. Menurutnya sebuah foto maupun video dalam Instagram juga termasuk ranah privasi dalam penggunaan model hijabers di Instagram.

"Kalo diliat dari feed Instagram aku tidak ada postingan. Karena males aja dan biar menjadi model hijab menjadi bagian dari privasi" (wawancara informan 4, 22 April 2021)

Melihat perkembangan penggunaan busana dan cara orang untuk berpakaian dapat mendefinisikan diri mereka sendiri. Tidak terkecuali perkembangan busana hijab. Terlebih hijab memberikan kesempatan bagi perempuan untuk dapat menentukan identitas diri mereka (Huromaini, 2017). Hijab sendiri juga merupakan busana dari cerminan perempuan yang Islami. Tren hijabers saat ini lebih mengedepankan cara berpakaian yang fashionable dan modern membuat model hijabers mulai bermunculan (Huromaini, 2017). Model hijabers seringkali 
dilakukan oleh pengguna akun yang memiliki pengikut yang banyak dan memiliki citra positif. Dalam penelitian ini informan memiliki referensi akun Instagram guna membentuk pribadi yang menurutnya ideal dalam Instagram. Komunikasi dunia maya melalui media sosial dianggap sebagai tempat ideal untuk bereksperimen dan melakukan eksplorasi pencarian identitas (Mustika, 2018). Dari hasil wawancara informan menyatakan:

"Ada mas karena kita manusia kalau kita melihat postingan orang bagus tentunya kita pengen juga seperti itu contoh saat ini ada gaya hijab baru sehingga kita bisa menirunya dan memposting ulang missal meniru selebram dan artis seperti citra kirana, biasanya saya menirui gaya hijabnya" (wawancara informan 2, 22 April 2021)

"Ada sih meniru missal selebgram tak jadiin bahan referensi doang gitu misalnya kaya outfitnya contoh selebgramnya itu seperti mega isyanti yang saya jadikan referensi hijab yang ingin saya tampilin" (wawancara informan 3, 22 April 2021)

Individu selaku pemilik utama informasi ingin berada dalam kontrol karena ada risiko tentang bagaimana informasi ini dikelola (Sugiarto, 2017). Informan dalam kontrol informasi seringkali melakukan penyesalan setelah mengunggah sebuah konten yang menurutnya tidak sesuai dengan harapanya. Temuan dalam penelitian ini, informan menyatakan bahwa delete dan archive unggahan Instagram.

"Ada dong. Alasannya habis dilihat gitu apa sih ini alay banget kadang kek gitu terus kalo merasa gak perlu lagi fotonya ya aku delete gitu aja sih lebih ke nyortir ke suatu hal yang tidak penting gitu aja sih yang enggak untuk ditampilin di publik" (wawancara informan 3, 22 April 2021)

Petronio dalam (Mustika, 2018) menyatakan sistem manajemen menyediakan sebuah struktur untuk memahami cara informasi pribadi ditangani. Misalnya menentukan siapa yang menerima pengungkapan, kapan, seberapa banyak atau sedikit, dimana pengungkapan tersebut, dan bagaimana seseorang bisa menyembunyikan informasi tersebut. Merujuk pada teori manajemen privasi komunikasi yaitu sebagai teori mendasar mengenai aturan yang kemudian dapat dipahami bahwa setiap individu biasanya memiliki aturan untuk mengelola informasi pribadi mereka (Dianiya, 2021). Petronio dalam (Mustika, 2018) ketika seseorang mengungkapkan perasaan pribadi kepada publik seringkali berisiko karena dapat menimbulkan rasa malu (feel embarrassed), rasa tidak nyaman (feel uncomfortable), dan perasaan somehow exposed (Petronio, 2002).

Pada dasarnya, individu menghargai privasi karena privasi merupakan kontrol seseorang akan informasi, batasan interpersonal yang diatur seseorang saat berinteraksi dengan orang lain (Nurbaiti \& Anshari, 2020). Dikarenakan penggunaan dari privat akun Instagaram yang dilakukan informan untuk memfilter akun yang tidak dikenal dan bisa membuat rasa aman, informan tidak memiliki tekanan dalam mengatur feedback di unggahanya. Terlihat dalam respon akun Instagram dalam kolom komentar, informan aktif untuk membalas setiap respon orang lain. Temuan dari observasi akun Instagram informan sesuai dengan apa yang informan katakan pada wawancara. Dimana informan aktif dalam membalas komentar akan tetapi masih adanya sedikit filter untuk orang yang tidak memiliki keintiman hubungan dengan penggunaan emoticon.

"Kalo untuk komentar, jika ada teman2 berkomentar tentunya saya akan melihat seperti apa komentarnya dan saya juga memfilter komentar dari teman2 saya yang sepertinya harus dibals seperti apa, yang hanya di beri emoticon seperti apa itu tetep saya filter. Biasaya kalo komentar dipostingan saya itu kan kebanyakan positif karena saya cewek ya mas seperti contoh memuji saya. Lah dikarenakan kita di puji orang maka saya akan membalasnya juga dan apabila ada komentar yang mungkin kurang baik saya memfilternya dengan didiamkan saja, diambil pelajarannya dari komentar2 yang lain" (wawancara informan 2, 22 April 2021)

"Kalo aku tu biasanya ngefilter kalo ada orang yang aku gak kenal berkomentar. Biasanya sih aku Cuma like aja sih alo ke orang yang gak dikenal gitu. Tapi kalo aku kenal sih pasti aku bales sih. Kalo komentar orang yang enggak kenal itu iasanya ngasih emot2 gitu sih missal emot love gitu terus responnya itu aku like doang" (wawancara informan 3, 22 April 2021)

Adanya sikap selektif yang terkait dengan teori communication management privacy pada komunikator nyatanya bermanfaat apabila dilakukan dalam penggunaan sosial media karena 
sebagai komunikator atau pemilik akun dapat memilih siapa saja komunikan yang dapat melihat story dan menjaga hubungan sosial khususnya dalam pertemanan yang juga berhubungan dengannya masing-masing komuniktor di dunia nyata (Dianiya, 2021).

\subsection{Aturan dalam Mengelola Privasi}

Merujuk pada teori manajemen privasi komunikasi yiatu sebagai teori mendasar mengenai aturan yang kemudian dapat dipahami bahwa setiap individu biasanya memiliki aturan untuk mengelola informasi pribadi mereka (Dianiya, 2021). Terlebih dalam realitasnya terdapat keunikan yang dimiliki oleh pengguna akun Instagram model hijabers yaitu adanya faktor bahwa akun tersebut sebagai tempat untuk berjualan. Sehingga terdapat aturan bahwa informan merasa dalam unggahan yang dilakukan terlihat dari feed Instagram harus mencerminkan sebagai pribadi yang memiliki citra positif. Hasil yang diperoleh saat wawancara ini berbanding lurus dengan temuan penelitian saat observasi akun Instagram informan. Dimana pada realitanya masing masing informan memperlihatkan unggahan yang menampakan kecantikan saat dirinya menggunakan hijab. Pengelolaan privasi yang dilakukan dengan membentuk pengungkapan positif dapat menjadi hal yang penting dalam membangun suatu hubungan (Dianiya, 2021).

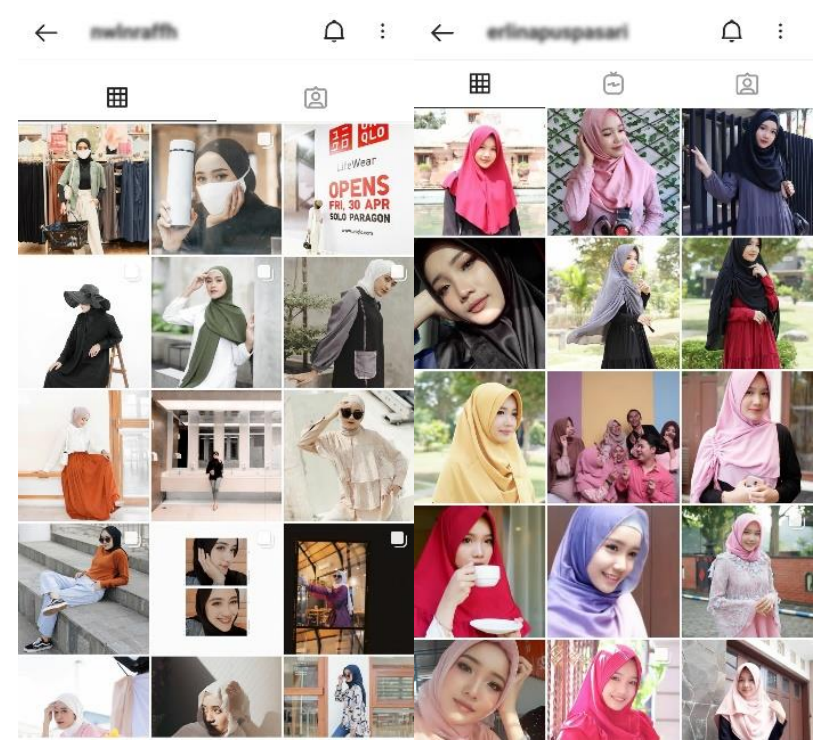

Gambar 4. Feed akun Instagram model hijabers

Konten yang diperlihatkan oleh model hijabers dalam akun Instagram memiliki fokus pada konten kecantikan dan ketertarikan pada fashion. Hal ini selaras dengan keberadaan informan sebagai media branding sebuah produk. Temuan yang diperoleh peneliti berbanding terbalik dengan penggunaan akun Finstagram dimana konten yang diunggah mulai dari keluh kesah, lelucon internal, hingga foto diri yang memalukan (Nurbaiti \& Anshari, 2020).

"Konten keseharian aku yaitu tentang jalan jalan, makan, make up. Kalo hijab itu pasti di feed aku. Aku sih sebenere suka foto juga sih sebulan sekali bikin feed" (wawancara informan 1, 24 April 2021)

"Konten fashion sih. Fashion yang lebih ke hijab fashion. Missal ke hijab apa sih yang lagi ngetren/ yang anah2 yang belum banyak dikenal lha terus itu aku jadiin konten gitu biasanya" (wawancara informan 3, 22 April 2021)

Terjadi keunikan yang dilakukan oleh informan 4 sebagai model hijabers di media sosial Instagram. Dimana dalam akun Instagramnya tidak terdapat unggahan di feed Instagram. Informan 4 merasa bahwa menjadi model hijabers juga merupakan bagian dari informasi privatnya. Sehingga membuat untuk tidak diperlihatkan di Instagram. Pada penelitian yang dilakukan oleh peneliti terdahulu terhadap pelajar, mahasiswa, dan karyawan berjudul Manajemen Privasi pada Pengguna Media Sosial Instagram berbanding terbalik dengan apa yang 
ditemukan oleh peneliti, dimana dalam penelitian tersebut status pekerjaan diperlihatkan di media sosial untuk meningkatkan citra positif informan (Kamilah \& Lestari, 2020). Temuan ini juga dinyatakan dalam wawancara informan.

"Bisa dilihat di feed Instagram aku, disitu tidak diperlihatkan kalau saya model hijab. Menurutku menjadi model hijab tidak perlu diperlihatkan dalam sosial media kita. Karena itu bagian dari pekerjaan, ruang dari privasi. Biar orang terdekat saja yang tahu" (wawancara informan 4, 22 April 2021)

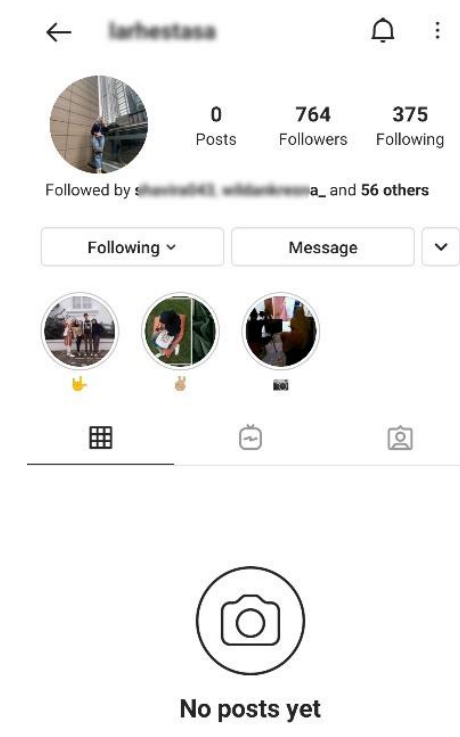

Gambar 5. Informan tidak memiliki unggahan di feed Instagram

Aturan dalam memposting unggahan di Instagram informan memilih untuk berhati hati untuk memposting sesuatu. Disebutkan dalam wawancara informan mengakui terdapat informasi privat berupa identitas diri. Identitas mampu untuk menjadi daya tarik dan motif untuk pelaku kejahatan (Putri, Nirwana \& Sobari, 2010). Menurutnya ketika mengunggah sebuah identitas diri di media sosial Instagram akan menimbulkan reaksi sosial yang membahayakan diri mereka sendiri. Hal ini dilakukan karena informan juga merasa akan adanya pelaku yang melakukan pencurian identitas. Cyber-deception-and thefts merupakan salah satu dampak negatif berupa pencurian dan penipuan melalui dunia maya dimana kegiatan ini dilakukan dengan mencuri, membajak misalnya pencurian identitas untuk keperluan pembajakan oleh orang yang tidak berhak (Putri, Nirwana \& Sobari, 2010). Walaupun dikatakan oleh informan belum sepenuhnya mengalami kegiatan dari kejahatan dari bahaya privasi manajemen, informan menggunakan privat akun Instagram untuk membatasi dan memfilter audiens dengan tujuan antisipasi.

"Pertimabangan saya dalam mengelola informasi privat adalah lebih berhati hati dalam mengelola sesuatu. Khususnya yang berhubungan dengan identitas diri. Karena ketika mengeshare identitas diri dapat memicu reaksi sosial yang dapat menyalahgunakan" (wawancara informan 1, 24 April 2021)

Aturan dalam unggahan yang dimiliki oleh akun Instagram model hijabers adalah menghindarinya sesuatu konten unggahan, caption, foto maupun video, feedback berupa komentar maupun direct messsage berupa sesuatu yang negatif yang dapat merugikan orang lain. Petronio dalam (Mustika, 2018) Ketika seseorang mengungkapkan perasaan pribadi kepada publik seringkali berisiko karena dapat menimbulkan rasa malu (feel embarrassed), rasa tidak nyaman (feel uncomfortable), dan perasaan somehow exposed.

Informan juga merasa bahwa dalam diri mereka perlu untuk mengerti sesuatu yang disukai maupun tidak disukai oleh audiens yang melihat unggahanya di Instagram. Sebagai kontrol batasan yang dilakukan untuk menghindari potensi untuk menimbulkan dampak bersifat 
negatif. Alasanya yang membuat para pengguna Instagram melakukan manajemen privasi pada akun Instagramnya karena ingin merasa aman akan adanya penyalahgunaan informasi privasi mereka (Kamilah \& Lestari, 2020). Dinyatakan dalam hasil temuan wawancara informan menyatakan bahwa butuh berkali kali untuk memikirkan upload unggahan di Instagram.

"Berkali kali kadang aku upload aku hapus lagi. Caption itu yang quotes kehidupan, aku tu pengen nunjukin kalo hidup tuh kaya gini missal ya itu yang nge support fotonya. Tapi kalo sekarang tu jarang nulis caption, biasanya Cuma emot aja" (wawancara informan 1, 24 April 2021)

"Sebenarnya tidak kehitung sih. Malah malah bisa jadi gak keupdate jika gak ada caption nya. Balik lagi ke caption ku bermanfaat gak ya. Kalo amu ngelawak garing gak ya. Kalo aku pengennya caption ku itu yang gak menye banget gitu. menye itu maksdnya centil atau kemayu gitu lho" (wawancara informan 3, 22 April 2021)

Temuan lain dalam penelitian yang ditemukan oleh peneliti adalah dimana pada realitanya saat membentuk kesan di media sosial Instagram oleh model hijabers ingin menunjukan kesan simpel dan elegan sebagai kesan ideal mereka.

"Simple dan elegan. Jadi gak terlalu heboh banget tapi masih enak di pandang gitu sih. yang gak neko neko yaudah gini nih hijab yang simple elegant dan casual tuh seperti ini dan yang apa adanya" (wawancara informan 3, 22 April 2021)

\subsection{Ketegangan Dialektis yang Dialami Ketika Akan Menyampaikan Informasi Privat}

Ketegangan dapat dikatakan sebagai ketakutan yang dialami oleh suatu individu (Putri, Nirwana \& Sobari, 2010). Ketegangan dialektis merupakan hal hal yang berlangsung secara terus menerus yang terjadi karena adanya ketegangan yang muncul dari dalam budaya yang berbeda (Sugiarto, 2017). Ketika individu dihadapkan pada pilihan untuk membuka atau menutup diri kepada orang lain, di dalam diri individu tersebut akan ada gaya tarik menarik untuk mengungkapkan atau tetap menyimpan informasi privat tersebut. Gaya tarik menarik untuk mengungkapkan atau tetap menyimpan informasi privat inilah yang disebut dengan ketegangan dialektik (Sugiarto, 2017). Dari hasil temuan data penelitian, informan mengalami ketegangan dialektik saat akan membuka diri kepada orang lain. Dimana masing masing informan merasa memiliki ketakutan atau ketegangan dalam mengungkap informasi dalam akun Instagramnya dikarenakan adanya nilai dari audiens yang tidak sependapat dan kontradiksi. Seperti yang dinyatakan oleh informan 4.

"Rasa takut dan cemas itu ada, karena di media yang dapat dilihat oleh banyak orang takutnya andai saya salah atau dinilai negatif buat orang lain dalam postingan saya itu yang membuat untuk mengurungkan diri untuk mengunggah" (wawancara informan 4, 22 April 2021)

Disamping itu, terdapat pengalaman negatif yang dialami oleh informan yang memunculkan ketegangan dialektis. Sehingga mereka menggunakan fitur privat akun untuk memfilter audiens yang dapat melihat aktivitasnya di media sosial Instagram. Seperti halnya yang dipaparkan oleh informan 1 saat wawancara. Fitur yang digunakan oleh model hijabers dalam menggunakan Instagram salah satunya adalah penggunaan privat akun Instagram. Hal ini dilakukan karena adannya ketakutan yang dialami oleh masing masing informan saat melakukan unggahan di Instagram. Dalam hal ini terjadi karena informan mengalami pengalaman maupun respon negative yang didapat oleh pengguna lain saat menggunakan Instagram. Seseorang merasa memiliki ketakutan/ketegangan dalam mengungkap informasi dikarenakan adanya lawan/kontradiksi (Putri, Nirwana \& Sobari, 2010).

"Ada sih dulu itu komentar negative itu pun langsung aku hapus. Seperti komentarnya itu lebih kearah tubuh berbau saru itu lo. Lebih ke arah sensitive" (wawancara informan 1, 24 April 2021)

Temuan ini serupa dengan penelitian terdahulu berjudul Manajemen Komunikasi Privasi Kaum Lesbian di Kota Samarinda dimana dalam temuan tersebut informan juga mengalami ketegangan yang sama akan tetapi tidak begitu besar (Sugiarto, 2017). Dalam penelitian lain berjudul Management privacy dalam penggunaan fitur "close friend" di Instagram karena adanya keyakinan kepada daftar yang dipilihnya meskipun tetap memiliki ketegangan dalam mengungkapkan informasi pribadi atau informasi yang disembunyikannya untuk orang lain 
(Dianiya, 2021). Dari keterangan informan, peneliti dapat mengambil kesimpulan bahwa banyak informasi privat yang tidak dapat diunggah karena berkaitan dengan ketegangan dialektik di media sosial Instagram. Ketegangan dialektik membuat informan cemas hingga mengurungkan niat untuk melakukan sebuah unggahan. Petronio menyatakan bahwa orang mendefinisikan informasi privat sebagai informasi mengenai hal-hal yang sangat berarti bagi mereka (Sugiarto, 2017).

\section{PEMBAHASAN}

Model hijabers asal Surakarta dalam mengaplikasikan Instagram memiliki manajemen privasi untuk kenyamanan mereka. Temuan ini sesuai dengan penelitian terdahulu berjudul "Manajemen Privasi pada Pengguna Media Sosial Instagram" terkait alasanya membuat para pengguna Instagram melakukan manajemen privasi pada akun Instagramnya karena ingin merasa aman akan adanya penyalahgunaan informasi privasi mereka (Kamilah \& Lestari, 2020). Informan dalam penelitian ini menentukan siapa yang menerima pengungkapan, kapan, seberapa banyak atau sedikit, dimana pengungkapan tersebut, dan bagaimana seseorang bisa menyembunyikan informasi tersebut. Dapat diartikan bahwa manajemen privasi yang dilakukan oleh model hijabers di Instagram memiliki filter audiens dan kontrol konten unggahan sehingga tetap menjaga kenyaman maupun citra dalam menggunakan Instagram. Sistem manajemen menyediakan sebuah struktur untuk memahami cara informasi pribadi ditangani (Petronio, 2002).

Peneliti melihat adanya kontrol yang dilakukan oleh para informan dalam membagikan informasi yang menurut para informan merupakan hal yang cukup privasi tentang diri mereka dengan cara tersendiri. Model hijab memiliki strategi manajemen privasi untuk kenyamanan dalam menggunakan Instagram. Berbeda dengan temuan yang dilakukan oleh Ferisa Nurul Kamilah, Sri Budi Lestari (Kamilah \& Lestari, 2020) berjudul "Manajemen Privasi pada Pengguna Media Sosial Instagram" dimana mereka menggunaan akun kedua untuk mempertahankan citra diri atau gambaran baik tentang dirinya di akun utama Instagramnya, model hijab Surakarta tetap memperlihatkan identitas asli dalam akun Instagram dan tidak menggunakan akun kedua.

Manajemen privasi yang dilakukan pada akun utama Instagram lebih berfokus kepada hal hal yang bersifat tertutup seperti informasi mengenai keluarga dan nomor kontak pribadi. Di dalam akun Instagram informan tetap memperlihatkan identitas asli mereka. Konteks yang menurut masing masing informan positif diperlihatkan untuk membuat orang tertarik dan menyukai unggahannya di Instagram. Konteks dari informasi yang mereka unggah menjadi sebuah pertimbangan yang paling utama bagi pengguna Instagram. Dalam penelitian ini diketahui bahwa para informan cenderung memilih informasi yang tidak akan menimbulkan kesalahpahaman dan cenderung disukai oleh para followersnya. Temuan ini berbeda dengan penelitian yang dilakukan berjudul Manajemen Komunikasi Privasi Seorang Mantan Pria Simpanan dimana manajemen privasi pria simpanan tidak memperlihatkan identitas mereka sama sekali dan menutup informasi dirinya sebagai seorang mantan pria simpanan yang sempat berhubungan dengan laki-laki homoseksual (Njotorahardjo, 2008). Temuan lain dalam kelompok kaum Lesbian di Samarinda memutuskan untuk tidak "come out/membuka diri" karena kerapkali mendapatkan penolakan dari keluarga dan teman yang bisa memberi pengaruh komunikasi dan psikologis yang negatif (Sugiarto, 2017).

Alasannya yang membuat para pengguna Instagram melakukan manajemen privasi pada akun Instagramnya karena ingin merasa aman akan adanya penyalahgunaan informasi privasi mereka. Selain itu, adanya pengalaman pengalaman yang dialami oleh beberapa informan berupa komentar negatif. Perbedaan keteangan dialektis dalam penelitian terdahulu seorang homoseksual merasa lega ketika informasi bersifat privat diketahui oleh orang lain sehingga membuat dirinya lebih terbuka walaupun denan rasa takut (Njotorahardjo, 2008).

\section{KESIMPULAN}

Berdasarkan penjelasan di atas, bisa ditarik kesimpulan kontrol manajemen privasi yang dilakukan oleh model hijabers Surakarta di Instagram dalam dengan cara menggunakan privat 
akun Instagram dan mengatur konten unggahan dari foto, video maupun caption hingga adanya filter audiens karena merupakan ranah privasi mereka. Penelitian ini telah menggambarkan manajemen privasi di Instagram yang dilakukan oleh model hijabers melalui fitur privat akun Instagram. Peneliti merekomendasikan untuk penelitian selanjutnya meneliti dari sudut pandang audiens dalam merespon manajemen privasi melalui privat akun yang dilakukan oleh subjek penelitian.

\section{UCAPAN TERIMA KASIH}

Rasa syukur serta terimakasih saya ucapkan kepada Allah SWT yang telah memberikan kemudahan dalam mengerjakan penulisan penelitian ini. Peneliti mengucapkan terimakasih kepada semua pihak yang telah membantu menyelesikan penelitian ini secara baik. Terimakasih peneliti ucapkan juga kepada 4 informan yang telah bersedia membantu penelitian ini. Terimakasih saya ucapkan kepada orang tua dan seluruh teman yang telah memberikan dukungan dalam proses penelitian ini.

\section{DAFTAR PUSTAKA}

Anggito, A., \& Setiawan, J. (2018). Metodologi Penelitian Kualitatif (E. Lestari, ed.). CV Jejak.

Ardiyanti, H. (2018). SWAFOTO : Sebuah Pendekatan Teori Manajemen Privasi Komunikasi. 9(1), 101-117.

Beam, M. A., \& Child, J. T. (2018). Context collapse and privacy management : Diversity in Facebook friends increases online news reading and sharing. https://doi.org/10.1177/1461444817714790

Dianiya, V. (2021). Management privacy dalam penggunaan fitur "close friend" di Instagram. 5(March), 249-266. https://doi.org/10.25139/jsk.v5i1.2652

Hollenbaugh, E. E. (2019). Privacy Management Among Social Media Natives : An Exploratory Study of Facebook and Snapchat. https://doi.org/10.1177/2056305119855144

Huromaini, N. (2017). Studi Analisis Pemaknaan Hijabers Community Surabaya Terhadap Hijab dalam Film 99 Cahaya di Langit Eropa. 3/No. 3(September 2016).

Iman, M. (2020). Pengguna Instagram di Indonesia Didominasi Wanita dan Generasi Milenial. Good News From Indonesia.

Kamilah, F., \& Lestari, S. (2020). Manajemen Privasi pada Pengguna Media Sosial Instagram.

Kriyantono, R. (2014). Teknik Praktis Riset Komunikasi. Jakarta: Prenadamedia.

Lestari, M. P., \& Kusuma, R. S. (2019). Hubungan Romantis Di Media Sosial (Resepsi Pengguna Terhadap Keterbukaan Hubungan Romantis Yang Diunggah Selebgram Di Instagram). 11(1), 28-44.

Masur, P. K., \& Scharkow, M. (2016). Disclosure Management on Social Network Sites : Individual Privacy Perceptions and User-Directed Privacy Strategies. https://doi.org/10.1177/2056305116634368

Mustika, R. (2018). Privasi pada remaja di media sosial. 14 No. 2, 111-120.

Nainggolan, V., Rondonuwu, S., \& Waleleng, G. J. (2017). media, telah memberikan dampak terhadap situs- situs komunikasi, dari sekedar. 1-15.

Nurbaiti, A., \& Anshari, I. (2020). Manajemen Privasi di Situs Jejaring Sosial: Studi Kasus Penggunaan Finstagram untuk Voyeurisme Termediasi. 1(September), 114-134.

Sugiarto, I. A. (2017). Manajemen Komunikasi Privasi Kaum Lesbian Di Kota Samarinda. 5(3), 580-592.

Sugiyono. (2010). Metode Penelitian Kuantitatif Kualitatif dan R\&D. Bandung: Alfabeta. 
Suh, J. J., \& Hargittai, E. (2015). Privacy Management on Facebook : Do Device Type and Location of Posting Matter? https://doi.org/10.1177/2056305115612783

Wolf, R. De. (2019). Contextualizing how teens manage personal and interpersonal privacy on social media. https://doi.org/10.1177/1461444819876570 